\title{
Effect of Annickia polycarpa (Stten and Mass.) Annonaceae, leaf extract on chemo-suppression of hyperparasitemia, body weight, hematological indices and survivor time of Plasmodium berghei infested mice in the Peter's test
}

\section{Frederick Ayertey}

Centre for Plant Medicine Research, Mampong-Akwapim

Emmanuel Kofi Kumatia ( $\square$ kofi2rhyme@yahoo.com )

Centre for Plant Medicine Research. Mampong-Akwapim, Ghana https://orcid.org/0000-0002-7244-

2751

Godfrey Kyaakyile Bagyour

University for Development Studies - Navrongo Campus

Kenneth Opare Asare

New Zealand Institute for Plant and Food Research Ltd

Valantine Chi Mbatchou

University of Development Studies. Navrongo Campus. Tamale Jonathan Dabo

Forest Resaerch Institute of Ghana. Kumasi.

\section{Research}

Keywords: Antimalaria activity, Annickia polycarpa, Red blood cells, Hemoglobin, White blood cells, platelets, Alkaloids, Saponins, Phenolic compounds

Posted Date: December 3rd, 2019

DOI: https://doi.org/10.21203/rs.2.18016/v1

License: (1) This work is licensed under a Creative Commons Attribution 4.0 International License. Read Full License 


\section{Abstract}

Background: Malaria is an infectious disease that is spread through the bite of female anopheles mosquito resulting in the death of hundreds of thousands of people per year. Medicinal plants provide crude extracts and purified compounds for malaria treatment. Annickia polycarpa is one of such plants whose bark is used for this purpose. However, the antimalaria effect of its leaf is not known. We hereby report the investigation of antimalaria effect of $A$. polycarpa leaf.

Methods: Antimalaria effect of the ethanol extract of A. polycarpa leaf (APLE) was investigated in P. berghei infested ICR mice in the Peter's test. The effect of the extract on development and chemosuppression of hyperparasitemia, reduction in body weight and mean survival time were evaluated. Full blood count analysis on the infected mice were performed to determine the effect of treatment with APLE on hematological indices such as red and white blood cells and platelets. Acute toxicity and phytochemical tests of the extract were also performed.

Results: APLE administered orally at 50, 200 and $400 \mathrm{mg} / \mathrm{kg}$ produced profound dose-dependent chemosuppressive effect of $89.37-95.50 \%$ of P. berghei after 4 consecutive days of treatment which compares with $86.22 \%$ obtained for Quinine $30 \mathrm{mg} / \mathrm{kg}$ i.m. under the same regimen. APLE also protected the mice against reduction in body weight associated with malaria which was $P<0.05$ at $50 \mathrm{mg} / \mathrm{kg}$. Furthermore, APLE promoted dose-dependent mean survival time in the Kaplan-Meier curve. Only $25.0 \%$ of mice in the negative control group survived after 30 days compared to $100 \%$ survival for mice in APLE $400 \mathrm{mg} / \mathrm{kg}$ and Quinine $30 \mathrm{mg} / \mathrm{kg}$ groups. The results from the full blood count shows that APLE caused $(P<0.05)$ dose dependent increase in RBC, HGB, HCT, WBCs, lymphocytes and platelets. The LD50 of APLE was above $5000 \mathrm{mg} / \mathrm{kg}$ p.o.

Conclusions: APLE showed profound antimalaria effect with very high margin of safety. Hematological alterations that resulted from treatment of with APLE indicate significant improvement in general health and safe recovery from the parasitic attack. These findings show that the leaf of A. polycarpa can also be used to treat malaria.

\section{Background}

Malaria is one of the neglected tropical diseases (NTDs) in most developing countries like Ghana, but raises serious health concerns globally. According to the 2017 World Health Organization (WHO) report, out of the 216 million reported cases, 445,000 people died of malaria in 2016 [1]. These incidences were mostly associated with the African regions as defined by the WHO and predominantly affected children and pregnant women [2]. The disease is caused by the Plasmodium parasite. Five (5) species of the Plasmodium parasite namely $P$. falciparum, $P$. vivax, $P$. ovale, $P$. malariae and $P$. knowlesi, have been identified as the causative agent of the disease in humans with the most pathogenic and deadliest specie is $P$. falciparum which also accounts for most of the malaria cases in Africa resulting in deaths of untreated and non-immune humans [3 - 4]. The incidence of malaria and its associated mortalities have 
been controlled extensively in recent times through the use of insecticide-impregnated mosquito nets, mosquito insecticide sprays and the use of chemotherapeutic agents such as artemisinin and artemisinin derivatives to treat the disease. Even though artemisinin-based combination therapy is the first-line of treatment of malaria in Ghana, the increasing resistance of the plasmodium parasite to artemisinin and other available antimalarials remains a serious challenge to the whole world, which calls for public health attention [5]. As a result, there is a need for the development of new anti-malaria drugs.

Medicinal plants have served as valuable sources of bioactive compounds for treatment of various diseases including parasitic infections. For example, it has been documented that, quinine and artemisinin which are predominantly used in the treatment of complicated malaria were obtained from Cinchona tree and Artemisia annua respectively [6 - 7]. The African continent is densely populated with numerous medicinal plants whose potentials have not yet been explored [8-10]. Typical of such medicinal plants is $A$. polycarpa which belongs to the Annonaceae family of flowering plants. Even though the ethanolic stem bark extract of $A$. polycarpa is known to treat malaria [11], there is no literature to show that the leaf has anti-malarial property. Hence, the aim of this study is to explore the anti-malarial potential of $96 \%$ ethanol extract of the leaf of A. polycarpa (APLE) in chloroquine sensitive Plasmodium berghei-infected mice.

\section{Methods}

\section{Chemicals}

Food grade ethanol was used for extraction. Quinine hydrochloride was purchase from Intravenous Infusions Limited (Koforidua, Ghana). Physiological saline was also purchased from Pharmanova Limited (Accra, Ghana). Chloroquine sensitive $P$. berghei ANKA strain was obtained from Noguchi Memorial Institute for Medical Research (Legon, Ghana).

\section{Collection and extraction of $\boldsymbol{A}$. polycarpa leaf}

The leaf of A. polycarpa was authenticated and collected by Mr. Jonathan Dabo, a botanist at the Forest Research Institute of Ghana (FORIG) Kumasi. Voucher specimen (FORIG 0012) was deposited the herbarium of FORIG. The air-dried leaf of $A$. polycarpa $(200 \mathrm{~g})$ was extracted with $3 \mathrm{~L}$ of $96 \%$ ethanol at room temperature. It was filtered after 4 days and re-extracted under the same conditions to ensure exhaustive extraction. The extracts were combined and evaporated to dryness in a rotary evaporator (Eyeler N1110, Tokyo-Japan). A dark green solid was obtained and labelled APLE. APLE was stored at 4 ${ }^{\circ} \mathrm{C}$ in air-tight container until use.

\section{Phytochemical Analysis}


The extract of APLE, $50 \mathrm{ml}$ was screened for 10 selected phytochemical constituents according to methods described previously [12]. The phytoconstituents tested were saponins, phenolic compounds, flavonoids, reducing sugars, cyanogenic glycosides, alkaloids, triterpenes, phytosterols, anthracinosides and polyuronides.

\section{Animals and ethics statement}

Female ICR mice (25-35 g) were obtained from the Animal Unit of the Centre for Plant Medicine Research (CPMR), Mampong-Akwapim, Ghana and used for the experiment. The mice were given unlimited access to commercial feed and water and kept in a controlled room of $12 \mathrm{~h}$ light and dark cycle with a temperature of $24 \pm 2{ }^{\circ} \mathrm{C}$ and humidity of $60-70 \%$. The experimental protocol which was approved by the ethics committee of CPMR was implemented according to the animal care and use guidelines for National Institutes of Health (NIH Publication No. 20-23) [13].

\section{Oral acute toxicity test}

The acute toxicity test was carried out in order to estimate the median lethal dose $\left(L D_{50}\right)$ of APLE as per the convention of the Organization for Economic Co-operation and Development, OECD, [14] with some modifications. A single oral dose of APLE $5000 \mathrm{mg} / \mathrm{kg}$ reconstituted with distilled water was administered to female ICR mice of body weight $21-28 \mathrm{~g}(n=6)$. The animals were observed for signs of toxicity such as autonomic, neurological and / or behavioral changes and mortality at $2 \mathrm{~h}$ interval for 24 $\mathrm{h}$ post administration of the extract. The mice were observed further for 14 more days.

\section{Maintenance of the parasite in the laboratory}

Chloroquine sensitive $P$. berghei ANKA strain were transferred into mice (at Noguchi Memorial Institute for Medical Research, Legon and transported to a laboratory at the Animal Experimentation Unit of the Centre for Plant Medicine Research. The $P$. berghei parasites were then maintained alive by serial transfer into naïve ICR mice after every 7 days for 21 days.

\section{Parasite inoculation}

Blood from donor mice with rising parasitemia of 20 - 30\% was diluted in physiological saline (Pharmanova Limited; Accra-Ghana) such that each $0.2 \mathrm{ml}$ contained $1.0 \times 10^{7}$ P. berghei-infected RBCs. ICR mice $(\mathrm{n}=30)$, were each injected with $0.2 \mathrm{ml}$ (i.p.) of diluted blood with the P. berghei-infected RBCs [15]. The parasitemia levels of the mice was determined by microscopy after $72 \mathrm{~h}$ of infection. 


\section{In-vivo evaluation of anti-plasmodial activity in the Peter's Test.}

Mice with parasitemia levels above $13 \%$ were randomly selected into five different groups, with five animals $(n=5)$ in each group. Group I received sterile water, group II received $35 \mathrm{mg} / \mathrm{kg}$ quinine as a reference drug (i.m.), Group III, IV and V received 50,200 and $400 \mathrm{mg} / \mathrm{kg}$ respectively of APLE (0.2 ml) orally for 4 more days post $P$. berghei-infection.

\section{Parasite monitoring}

The parasitemia levels in the blood of the $P$. berghei-infected mice were monitored using methods described previously [16]. Briefly, blood samples from each animal were taken onto a microscope slide by tail-bleeding on day 3, 5 and 8 post infection to prepare a thin film. The film of the blood was dried and fixed in methanol for 15 minutes, and stained in 10\% Giemsa stain for 25 minutes. Excess stain was washed off and the slide was made to dry. The film was then immersed in oil and viewed at $x 100$ magnification using the Olympus light microscope (Olympus CX21; Tokyo, Japan). The level of parasitemia was determined by counting the number of parasitized RBCs and normal RBCs per randomly selected fields.

The percentage parasitemia was calculated by:

[Due to technical limitations, the formula could not be displayed here. Please see the supplementary files section to access the formula.]

The percentage parasite suppression was calculated by;

[Please see supplementary files.]

\section{Hematological analysis}

Blood samples were collected from each animal by tail bleeding after the $8^{\text {th }}$ day post infection into Eppendorf tubes precoated with anti-coagulant (Na-EDTA). The blood samples, 50-80 $\mu \mathrm{L}$, was diluted in $420 \mu \mathrm{L}$ normal saline. Hematological parameters were determined by running a full blood count of the diluted blood using Abacus hem analyzer (Abacus 380; Budapest, Hungary). The dilution of the blood was accounted for by multiplying through by the dilution factor.

\section{Body weight analysis}

The body weight of the animals was monitored daily over the experimental period up to the $8^{\text {th }}$ day after inoculation. 


\section{Mean Survival Time (MST)}

The number and date of death of animals from each group was recorded during the experimental period and for further 22 more days after inoculation. The mean survival time (MST) was determined over a period of 30 days.

\section{Statistical Analysis}

The data was analyzed using graph pad prism version 6 and presented as mean \pm SEM. Variations were determined by comparative analysis using one-way analysis of variance (ANOVA), followed by Dunnett's multiple comparison test to determine where the variation lies. Variations were considered significant when $\mathrm{P} \otimes 0.05$.

\section{Results}

Yield of crude extract

APLE yielded $15.78 \% \mathrm{w} / \mathrm{w}$ of solid upon extraction.

\section{Phytochemical screening}

The result of the phytochemical screening is summarized in Table 1 below.

Table 1 Phytochemical constituents revealed in APLE

\begin{tabular}{lc}
\hline Constituent & Result \\
\hline Alkaloids & Present \\
Phenolic compounds & Present \\
Saponins & Present \\
Phytosterols & Present \\
Free reducing sugars & Present \\
Flavonoids & Absent \\
Triterpenes & Absent \\
Anthracenosides & Absent \\
Cyanogenic glycoside & Absent \\
Polyuronides & Absent \\
\hline
\end{tabular}

\section{Acute toxicity test and selection of doses of APLE for antimalarial activity test}

There was no death recorded after $48 \mathrm{~h}$ of observation and beyond. Surviving animals did not show any sign of toxicity such as pilo-erection, change in eye color, salivation, lachrymation, coma, abnormalities in breathing, reduced feeding and restriction in movement of the animals. The $\mathrm{LD}_{50}$ of the extract was estimated to be above $5000 \mathrm{mg} / \mathrm{kg}$ 
(p.o.). Three arbitrary doses (50, 200 and $400 \mathrm{mg} / \mathrm{kg}$ p.o.) lower than the $\mathrm{LD}_{50}$ value of the extract were selected for the anti-malaria activity assay.

\section{Chemo-suppression of $P$. berghei by APLE}

The average parasitemia of the $P$. berghei-infected mice was $22.78 \pm 0.93 \%$ on the $3^{\text {rd }}$ day post infection. It increased to $44.62 \pm 5.94 \%$ by the $8^{\text {th }}$ day in the negative control group, where infected mice received only sterile water (p.o.) for 4 days. However, the parasite levels of the groups treated with APLE at 50, 200 and $400 \mathrm{mg} / \mathrm{kg}$ p.o. for 4 days reduced significantly ( $\mathrm{P} \square 0.05$ ) to $2.64 \pm 0.40 \%, 4.74 \pm 1.15 \%$ and $2.01 \pm 0.25 \%$ respectively by day 8. Just as those treated with quinine (30 mg/kg i.m.) also reduced to $6.15 \pm 0.92 \%$ (Fig.1). The overall chemo-suppression for the various treatment groups are indicated in Table 2. APLE had a dose dependent suppression of parasite especially on the $8^{\text {th }}$ day. The micrographs in Fig. 4 further confirmed that there was reduction of parasitized RBCs in all treatment groups compared to the negative control.

Table 2 Effect of APLE/Quinine on P. berghei suppression in mice post infection.

$$
\text { Parasite Suppression (\%) }
$$

\begin{tabular}{lll}
\cline { 2 - 3 } Dose & Day 5 & Day 8 \\
\hline Negative Control & 00.00 & 00.00 \\
Quinine $(30 \mathrm{mg} / \mathrm{kg})$ & 61.45 & 86.22 \\
APLE $(50 \mathrm{mg} / \mathrm{kg})$ & 25.73 & 89.37 \\
APLE $(200 \mathrm{mg} / \mathrm{kg})$ & 64.69 & 94.08 \\
APLE $(400 \mathrm{mg} / \mathrm{kg})$ & 53.14 & 95.50 \\
\hline
\end{tabular}

Results are presented as percentage mean $(n=5)$.

\section{Effect of APLE or Quinine on survival time of $P$. berghei-infected mice}

The negative control had 75.0,62.5, 50.0 and $25.0 \%$ of animals surviving after the 4, 6, 7 and $15^{\text {th }}$ day post $P$. berghei infection. The APLE (50 and $400 \mathrm{mg} / \mathrm{kg}$ p.o.) and quinine (30 $\mathrm{mg} / \mathrm{kg}$, i.m.) treated groups had $100 \%$ survival up to the $13^{\text {th }}$ day, whereas only $66.7 \%$ of APLE (50 mg/kg p.o.) treated mice survived. The APLE (200 mg/kg) treated group had $83.3 \%$ survival on the $6^{\text {th }}$ day. On the $30^{\text {th }}$ day, it was observed that $100 \%$ of mice survived in both the quinine $(30 \mathrm{mg} / \mathrm{kg})$ and APLE $(400 \mathrm{mg} / \mathrm{kg})$ treated groups, while 25.0, 66.7 and $83.33 \%$ survived in the negative control, APLE 50 and $200 \mathrm{mg} / \mathrm{kg}$ respectively as depicted below in Figure 2.

Effect of APLE or Quinine on body weight of $P$. berghei-infected mice 
The body weight of mice were not affected significantly during and after the $P$. bergheiinfection (Fig. 3) Quinine (30 $\mathrm{mg} / \mathrm{kg}$ ) or APLE at all doses did not have any significant effect on the body weight except for APLE at $50 \mathrm{mg} / \mathrm{kg}$, in which there was significant improvement in body weight ( $\mathrm{P} \square 0.05$ ). The change in body weight after the $5^{\text {th }}$ and $8^{\text {th }}$ day post infection is shown in Table 3.

Table 3 Mean change in body weight of $P$. berghei infected mice after $5^{\text {th }}$ and $8^{\text {th }}$ day of infection.

Change in Body Weight (g)

\begin{tabular}{llc}
\cline { 2 - 3 } Dose & Day 5 & Day 8 \\
\hline Negative Control & $-1.67 \pm 0.26$ & $-1.50 \pm 0.32$ \\
Quinine $(30 \mathrm{mg} / \mathrm{kg})$ & $2.00 \pm 0.00$ & $2.00 \pm 0.63$ \\
APLE $(50 \mathrm{mg} / \mathrm{kg})$ & $-0.60 \pm 0.51$ & $-0.75 \pm 0.42^{*}$ \\
APLE $(200 \mathrm{mg} / \mathrm{kg})$ & $-1.00 \pm 1.05$ & $-2.20 \pm 1.02$ \\
APLE $(400 \mathrm{mg} / \mathrm{kg})$ & $-1.80 \pm 1.16$ & $-3.25 \pm 1.52$ \\
\hline
\end{tabular}

Results are presented as mean change in body weight \pm SEM. ${ }^{*} \mathrm{P}<0.05$ compared to negative control

\section{Effect of treatment on hematological parameters of $P$. berghei-infected mice on day 8 Effect of APLE on RBCs and their indices}

The summary of results of treatment of APLE on RBCs and their differentials are tabulated below (Table 4). APLE caused a dose dependent increase in RBC, HGB and HCT levels as compared to the negative control.

Table 4 Effect of Quinine / APLE treatment on Red Blood Cells (RBCs) indices in P. berghei infected mice on day 8 of parasite inoculation. 
Treatment Group

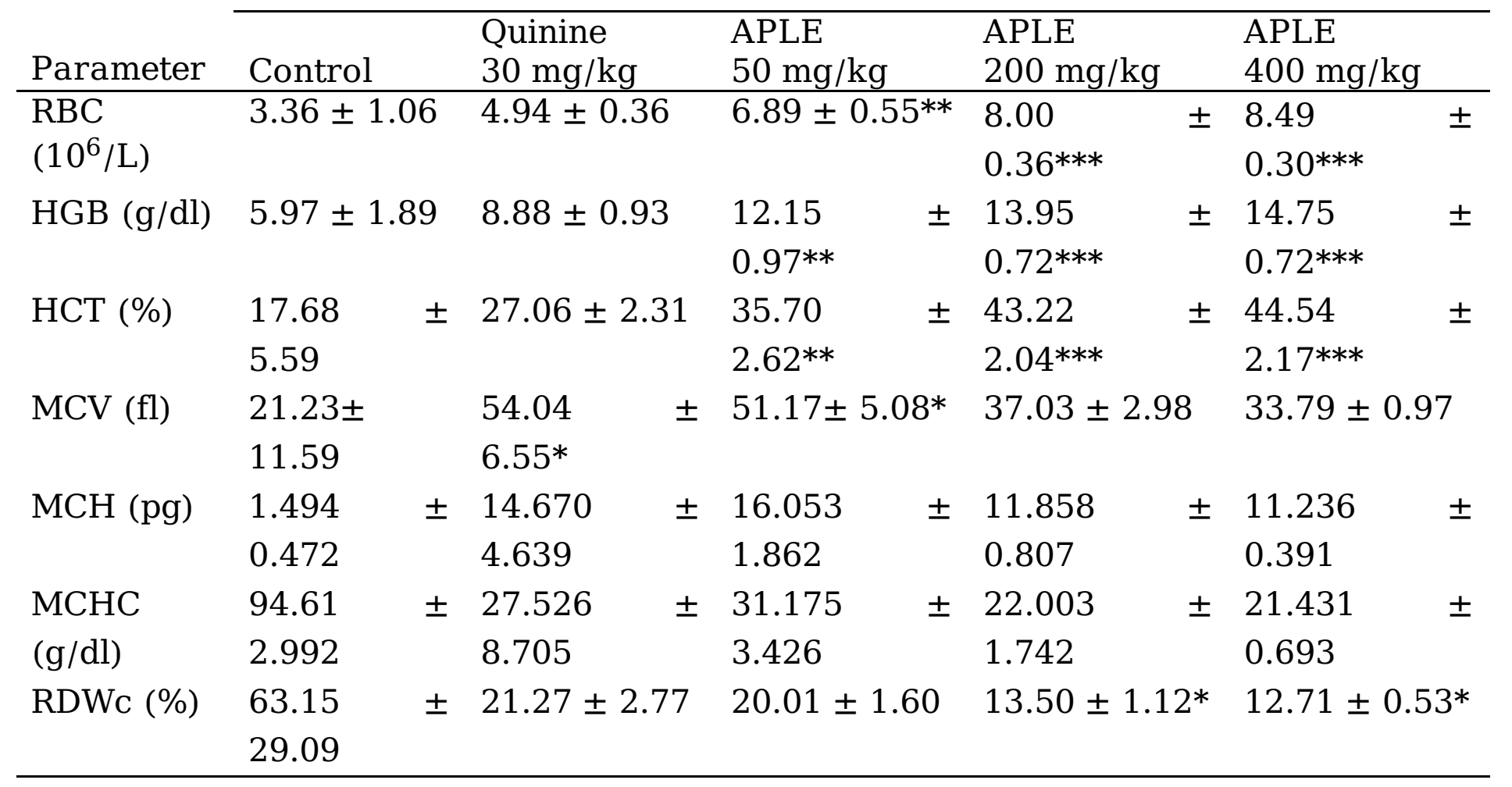

Results are presented as mean $\pm \mathrm{SEM} . * \mathrm{P}<0.05, * * \mathrm{P}<0.01, * * * \mathrm{P}<0.001$ compared to negative control.

\section{Effect of treatment with APLE on WBCs and indices}

The results obtained from the full blood count analysis of the effect of the extract on WBCs are below in Table 3. The APLE treatment groups had a dose dependent increase in WBCs with increasing lymphocytes levels. At the highest does, APLE caused a significant increase in the lymphocyte levels as compared to the negative controls. However, there were no significant difference in the WBC count in the treatment groups compared with the negative controls.

Table 5 Effect of Quinine /APLE treatment on White Blood Cells (WBCs) indices in $P$. berghei infected mice at the day 8 of parasite inoculation 
Treatment Group

\begin{tabular}{llllll}
\cline { 2 - 5 } rameter & & Quinine & APLE & APLE & APLE \\
& Control & $30 \mathrm{mg} / \mathrm{kg}$ & $50 \mathrm{mg} / \mathrm{kg}$ & $200 \mathrm{mg} / \mathrm{kg}$ & $400 \mathrm{mg} / \mathrm{kg}$ \\
\hline WBC $\left(10^{9} / \mathrm{L}\right)$ & $10.14 \pm 0.76$ & $6.43 \pm 1.10$ & $8.10 \pm 0.94$ & $9.11 \pm 1.37$ & $10.91 \pm 1.08$ \\
LYM $\left(10^{9} / \mathrm{L}\right)$ & $3.95 \pm 1.25$ & $0.00 \pm 0.00$ & $3.19 \pm 0.77$ & $4.52 \pm 1.20$ & $5.44 \pm 0.10$ \\
MID $\left(10^{9} / \mathrm{L}\right)$ & $2.16 \pm 0.68$ & $0.00 \pm 0.00$ & $2.27 \pm 0.71$ & $1.30 \pm 0.04$ & $1.79 \pm 0.26$ \\
GRA $\left(10^{9} / \mathrm{L}\right)$ & $5.22 \pm 1.65$ & $0.00 \pm 0.00$ & $3.85 \pm 0.60$ & $4.42 \pm 0.19$ & $4.59 \pm 1.60$ \\
LYM \% & $26.04 \pm 8.24$ & $0.00 \pm 0.00$ & $21.81 \pm 5.08$ & $27.30 \pm 6.33$ & $39.45 \pm 1.58$ \\
& & & & & \\
MID \% & $14.18 \pm 4.48$ & $0.00 \pm 0.00$ & $14.23 \pm 3.65$ & $9.46 \pm 0.39$ & $11.03 \pm 1.80$ \\
GRA \% & $34.40 \pm 10.90$ & $0.00 \pm 0.00$ & $26.48 \pm 4.27$ & $32.30 \pm 0.76$ & $26.03 \pm 7.50$ \\
\hline
\end{tabular}

Results are presented as mean \pm SEM.

\section{Effect of treatment with APLE on platelets and indices}

Effect of APLE on platelets and indices on day 8 after $P$. berghei infection is shown below in Table 6. APLE dose dependently increased platelets compared to the negative control. The effect on other platelet indices are also shown below (Table 6).

Table 6 Effect of Quinine /APLE treatment on platelet indices in P. berghei infected mice on the day 8 of parasite inoculation

\begin{tabular}{|c|c|c|c|c|c|c|c|c|c|}
\hline \multirow{3}{*}{$\begin{array}{l}\text { Parameter } \\
\text { PLT }\left(10^{9} / \mathrm{L}\right)\end{array}$} & \multicolumn{7}{|c|}{ Treatment Group } & \multirow{2}{*}{\multicolumn{2}{|c|}{$\begin{array}{l}\text { APLE } \\
400 \mathrm{mg} / \mathrm{kg}\end{array}$}} \\
\hline & \multicolumn{2}{|l|}{ Control } & \multicolumn{2}{|l|}{$\begin{array}{l}\text { Quinine } \\
30 \mathrm{mg} / \mathrm{kg}\end{array}$} & $\begin{array}{l}\text { APLE } \\
50 \mathrm{mg} / \mathrm{kg}\end{array}$ & \multicolumn{2}{|c|}{$\begin{array}{l}\text { APLE } \\
200 \mathrm{mg} / \mathrm{kg}\end{array}$} & & \\
\hline & $\begin{array}{l}453.35 \\
17.74\end{array}$ & \pm & $\begin{array}{l}444.18 \\
46.37\end{array}$ & \pm & $\begin{array}{l}513.87 \pm \\
14.00\end{array}$ & $\begin{array}{l}551.53 \\
89.02\end{array}$ & \pm & $\begin{array}{l}666.63 \\
64.21\end{array}$ & \pm \\
\hline PCT (\%) & $0.64 \pm 0.21$ & & $0.35 \pm 0.07$ & & $0.31 \pm 0.02$ & $0.32 \pm$ & & $0.39 \pm$ & \\
\hline MPV (fl) & $\begin{array}{l}150.71 \\
58.98\end{array}$ & \pm & $74.77 \pm 8.7$ & & $38.79 \pm 8.05$ & $\begin{array}{l}41.34 \\
7.64 *\end{array}$ & \pm & $\begin{array}{l}62.29 \\
13.42\end{array}$ & \pm \\
\hline PDWc (\%) & $\begin{array}{l}596.97 \\
235.04\end{array}$ & \pm & $\begin{array}{l}277.86 \\
27.19\end{array}$ & \pm & $185.16 \pm 7.45 *$ & $\begin{array}{l}213.90 \\
20.81 *\end{array}$ & \pm & $\begin{array}{l}289.48 \\
33.22\end{array}$ & \pm \\
\hline $\begin{array}{l}\text { P-LCC } \\
\left(10^{9} / \mathrm{L}\right)\end{array}$ & $33.74 \pm 21.1$ & & $\begin{array}{l}70.72 \\
13.46\end{array}$ & \pm & $\begin{array}{l}41.26 \\
13.77\end{array}$ & $\begin{array}{l}46.31 \\
21.74\end{array}$ & \pm & $\begin{array}{l}58.63 \\
26.38\end{array}$ & \pm \\
\hline P-LCR (\%) & $\begin{array}{l}282.18 \\
100.41\end{array}$ & \pm & $\begin{array}{l}153.49 \\
27.80\end{array}$ & \pm & $\begin{array}{l}72.25 \\
40.44\end{array}$ & $\begin{array}{l}75.40 \\
46.82\end{array}$ & \pm & $\begin{array}{l}100.56 \\
53.18\end{array}$ & \pm \\
\hline
\end{tabular}

Results are presented as mean \pm SEM. $* \mathrm{P}<0.05$, compared to negative control.

\section{Discussion}


Amidst the various malaria treatment challenges, access to anti-malarial medications and emergence of drug resistance are critical obstacles to be considered in ensuring absolute control and eradication of the disease in the sub-Saharan region. The possibility of improving on the quality and management of malaria cases in these regions includes a home-based management approach, which is a common practice in African [17-18]. The practice is not only limited to the use of efficacious herbal medicine which are cost efficient and devoid of toxic effects but also ensures that all persons have access to health care due to its readily availability. Medicinal plants serve as natural reserves, where new antimalarial agents could be obtained [19]. The stem bark of $A$. polycarpa has been established as an antimalarial agent [11], but there is no literature to validate the use of the leaf as anti-malarial agent. The current study therefore sought to evaluate the anti-malarial activity of the ethanolic leaf extract of $A$. polycarpa (APLE) and validate its traditional use.

Even though scientific validation of traditional remedies is rare, there are still evidence to indicate that it is constantly increasing especially in Africa [20]. A major consideration for validation according to WHO is the safety and effectiveness of the traditional medicine before its integration into the health care system [20]. The result of the acute toxicity test indicates that a single oral dose administration of APLE up to $5000 \mathrm{mg} / \mathrm{kg}$ in female ICR mice was safe without any observable signs of toxicity. This indicates that the doses tested (50, 200 and $400 \mathrm{mg} / \mathrm{kg}$ p.o.) were safe and the observed anti-malarial activity is not in any way associated with toxicity to normal tissues.

The extract (APLE) at the different doses (50, 200 and $400 \mathrm{mg} / \mathrm{kg}$ ) exhibited substantial and dose dependent chemo-suppression of $P$. berghei in the infected but treated mice after 4 days of treatment. The strong chemo-suppression of quinine $(30 \mathrm{mg} / \mathrm{kg}$ ) after day 2 (day 5 post $P$. berghei infection) of treatment, as compared to the APLE ( 50 and $400 \mathrm{mg} / \mathrm{kg}$ ), but the reverse on day 4 (day 8 post $P$. berghei infection) indicates that herbal medicine could be very effective but slow acting.

According to [15] if an extract results in an increased survival time in infected but treated groups as compared to untreated group, then the extract is considered active. APLE at the different dose levels protected at least $50 \%$ of the mice from death and ensured majority of the test population (more than $60 \%$ ) survived up to day 30 post infection. Mice treated orally with APLE $400 \mathrm{mg} / \mathrm{kg}$ survived (100\%) as compared to the negative control group. These results therefore showed that APLE is an active antimalaria agent.

Loss in body weight normally associated with P. berghei infection in mice is an indication of reduced appetite and disturbed metabolism, resulting in hypoglycemia (Fidock et al., 2004). The result indicates that there was no significant change in body weight in all extract treated groups compared to the negative controls on day 5 and day 8 post $P$. berghei infection. Simultaneously, increasing the dose of APLE resulted in loss in body weight. This could be attributed to the protective effect of the extract and the cumulative pathological alterations exhibited by plasmodium infection. Hence, a decline in body weight of the APLE treatment groups is a reflection of the parasite suppression. 
Alterations in hematological parameters are considered as markers of malaria, which may be pronounced probably due to rising levels of parasites [21]. P. berghei infection may present pathological conditions including that of anemia, leukocytosis and thrombocytosis depending on the severity of infection.

Anemia is a common symptom of malaria which is evaluated by measuring the levels of RBC, HCT/PCV, $\mathrm{HGB}, \mathrm{MCV}, \mathrm{MCH}, \mathrm{MCHC}$ and RDWc. The parasites attack RBCs and feed on the intracellular protein, hemoglobin (HGB), found in RBCs [22]. As the parasite population in the RBC increases, the cell raptures to release the parasites and their toxins into the blood stream. The released parasites attack and destroy new RBCs, constantly leading to the rapture and destruction of more cells especially in untreated cases resulting in reduced RBCs. Anemia due to malaria could be extremely complex and may involve a combination of factors not limited to accelerated hemolysis of only parasitized RBCs, but also accidental removal of unparasitized RBCs and ineffective erythropoiesis [21, 23). The extracts dose dependently increased the RBC, HGB and HCT levels as compared to the negative control group and quinine treated group. This means that the extract protected against the rapid hemolysis of parasitized RBCs.

The size of the RBCs is a further definition of the type of the anemia; normacytic (normal MCV), macrocytic (increased MCV) and microcytic (decreased MCV) [24]. According to [25], MCV levels in healthy mice ranges from 48.9-50 $\mathrm{U}^{3}$. The current report indicates that increasing dose of APLE is likely to cause a reduction in $\mathrm{MCV}, \mathrm{MCH}, \mathrm{MCHC}$ and RDWc levels, leading to possible hypochromic microcytic anemia.

The insignificant WBC count with increased lymphocytes in the APLE $(400 \mathrm{mg} / \mathrm{kg})$ treated group as compared to the negative control is an indication of a possible antibody (B lymphocytes) production / secretion due to anti-plasmodial treatment with the extract. However, high WBC levels in the negative controls is as a result of increased inflammation due to high parasitemia.

Plasmodium parasite infection causes platelets levels to reduce, with decreased clotting factors. This increases the propensity to bleed heavily when there is an injury as a result of thrombocytopenia associated with malaria. There was no significant difference in the platelet count of the APLE treatment groups as compared to the negative control group, even though there seem to be an increase in platelet levels in the groups treated with the extract. APLE at increasing dose levels is likely to raise the levels of platelet close to normal to prevent thrombocytopenia associated with malaria.

\section{Conclusion}

The ethanolic leaf extract of $A$. polycarpa showed an impressive chemo-suppression of $P$. berghei infection in mice. This may be due to the presence of biologically active phytochemicals like alkaloids, which are very necessary in the treatment of malaria. The $L_{50}$ of the extract is above $5000 \mathrm{mg} / \mathrm{kg}$ and did not show any sign of toxicity, hence, has wide margin of safety in the mice. The hematological alterations resulting from treatment by the extract are in favor in improving the general health and 
ensuring a safe recovery from the parasitic attack. The findings so far indicate that the leaves of $A$. polycarpa can also be used in the treatment of acute malaria.

\section{Abbreviations}

APLE - Anickia polycarpa leaf ethanol extract. RBCs-red blood cells. WBCs - White blood cells. HGBHemoglobin. $\mathrm{LD}_{50}-$ Mean lethal dose. p.o.-per oral. i.m.-intramuscular.

\section{Declarations}

\section{Ethical considerations}

Ethical clearance was granted by Research and Ethics Committee of the Centre for Plant Medicine Research (CPMR). Mampong-Akwapim, Ghana.

\section{Consent for publication}

All authors have given their consent for publication of this manuscript after they have reviewed it.

\section{Availability of data and materials}

The data set upon which the conclusions in this work were made are available from the corresponding author upon reasonable request.

\section{Competing interest}

The authors declare that they have no competing interest with respect to this work.

\section{Funding}

This study was supported by the authors.

\section{Authors' contributions}

EKK conceived the study and was involved in all stages of the investigations, data analysis, writing, corrections and proof reading and final editing of the manuscript. FA was involved in all stages of the investigations, data analysis and writing of the manuscript. GKB and VCM were involved in all stages of investigations, development of protocols for the investigations and data acquisition. KOA performed full blood count analysis and examinations using the microscope. JD was involved in conception of the study, identification, harvesting and processing of the plant material. 


\section{Acknowledgements}

The authors wish to express their sincere gratitude to the technical staff of Phytochemistry Department, Clinical laboratory Unit and Animal Experimentation Unit of Centre for Plant Medicine Research (CPMR). Mampong-Akwapim, Ghana.

\section{Authors' information}

${ }^{1}$ Department of Phytochemistry. Centre for Plant Medicine Research. Mampong-Akwapim. Ghana.

${ }^{2}$ Department of Chemistry and Applied Biochemistry. University of Development Studies. NavrongoCampus, Tamale. Ghana. ${ }^{3}$ Department of Clinicals. Centre for Plant Medicine Research. MampongAkwapim. Ghana. ${ }^{4}$ Forest Research Institute of Ghana. Kumasi.

\section{References}

1. World malaria report 2016. Geneva: World Health Organization; 2016.

2. World malaria report 2017. Geneva: World Health Organization; 2017.

3. Mueller I, Zimmerman PA, Reeder JC. Plasmodium malariae and Plasmodium ovale-the 'bashful'malaria parasites. Trends Parasitol. 2007; 23: 278 - 83.

4. Collins WE. Plasmodium knowlesi: a malaria parasite of monkeys and humans. Annu Rev Entomol. 2012; 57: 107-21.

5. Ashley EA, Dhorda M, Fairhurst RM, Amaratunga C, Lim P, Suon S, Sreng S, Anderson JM, Mao S, Sam B, Sopha C. Spread of artemisinin resistance in Plasmodium falciparum malaria. $\mathrm{N}$ England $\mathrm{J}$ Med. 2014; 371: 411-23.

6. Rates SMK. Plants as source of drugs. Toxicon. 2001; 39: $603-13$.

7. Li JW, Vederas JC. Drug discovery and natural products: end of an era or an endless frontier. Science $2009 ; 325: 161-65$.

8. Iwu MM. Handbook of African medicinal plants. CRC press. 2014.

9. Watt JM, Breyer-Brandwijk MG. The Medicinal and Poisonous Plants of Southern and Eastern Africa being an Account of their Medicinal and other Uses, Chemical Composition, Pharmacological Effects and Toxicology in Man and Animal. (Edn 2). 1962.

10. Burkill HM. The useful plants of tropical West Africa. Richmond, UK, Kew Royal Botanical Garden, London. 1985; 1: 252-53.

11. Anosa GN, Udegbunam RI, Okoro JO, Okoroafor ON. In vivo antimalarial activities of Enantia polycarpa stem bark against Plasmodium berghei in mice. $\mathrm{J} 2014$; 153: 531-34.

12. Trease GE, Evans WC. 13th (ed). London: ELBS/Bailliere Tindall; 1989.

13. Guide for the care and use of laboratory animals. National Academy of Sciences. USA. $8^{\text {th }}$ The National Academic Press, 2011. 
14. WHO, OECD guidelines for testing of chemicals. Acute oral toxicity - Acute toxic class. Geneva World Health Organization, 2001.

15. Fidock DA, Rosenthal PJ, Croft SL, Brun R, Nwaka S. Antimalarial drug discovery: efficacy models for compound screening. Nat. Rev. Drug Discov. 2004; 3: 509.

16. Arrey TP, Franzoi KD, Lee S, Lee E, Vivarelli D, Freitas-Junior L, Liuzzi M, Nolé T, Ayong LS, Agbor GA, Okalebo FA. In vitro antiplasmodial activities and synergistic combinations of differential solvent extracts of the polyherbal product, Nefang. BioMed Res. Int. 2014.

17. Aubouy A. Promotion of malaria home-based treatment in Africa: the dangers of creating a second health system. Int. Health, 2011; 3: 219- 20

18. Ferrer BE, Webster J, Bruce J, Narh-Bana SA, Narh CT, Allotey NK, Glover R, Bart-Plange C, SagoeMoses I, Malm K, Gyapong M. Integrated community case management and community-based health planning and services: a cross sectional study on the effectiveness of the national implementation for the treatment of malaria, diarrhoea and pneumonia. Malar. J. 2016; 15: 340

19. Halberstein, R. A. (2005). Medicinal plants: historical and cross-cultural usage patterns. Ann Epidemiol. 2005; 15: 686-99.

20. Qi Z. WHO Traditional Medicine Strategy. 2014-2023. Geneva: World Health Organization, 2013.

21. Facer CA. Hematological aspects of malaria. Infection and Hematology. Oxford: Butterworth Heinmann 1994.

22. Gavigan CS, Dalton JP, Bell A. The role of aminopeptidases in hemoglobin degradation in Plasmodium falciparum-infected erythrocytes. Mol Biochem Parasitol. 2001; 117: $37-48$.

23. Perrin LH, Mackey LJ, Miescher PA. Hematology of malaria in man. In Seminars in hematology. 1982.

24. Bessman JD, Gilmer JR, PR, Gardner FH. Improved classification of anemias by MCV and RDW. Am. J Clin Pathol. 1983; 80: 322-326.

25. Schnell MA, Hardy C, Hawley M, Propert KJ, Wilson JM. Effect of blood collection technique in mice on clinical pathology parameters. Hum Gene Ther. 2002; 13: 155-61.

\section{Figures}




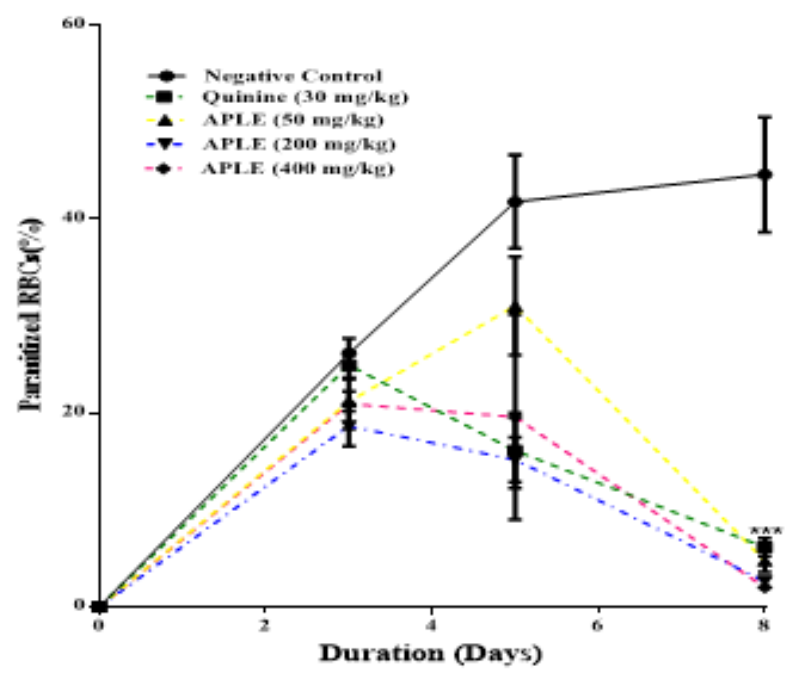

$\mathbf{A}$

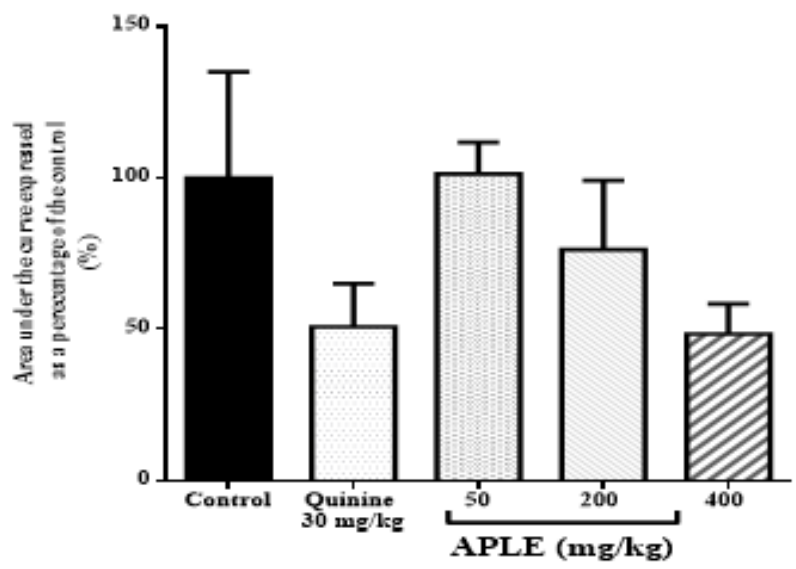

B

Figure 1

Effect of APLE or Quinine on parasitemia levels of P. berghei-infected mice. (A) represents time course curves and $(B)$ is the area under the curves normalized in the negative control, where mice were infected for $72 \mathrm{~h}$ and treated for 4 days. Results are presented as mean \pm S.E.M $(n=5)$. *ᄎ* $(P \leq 0.001)$.

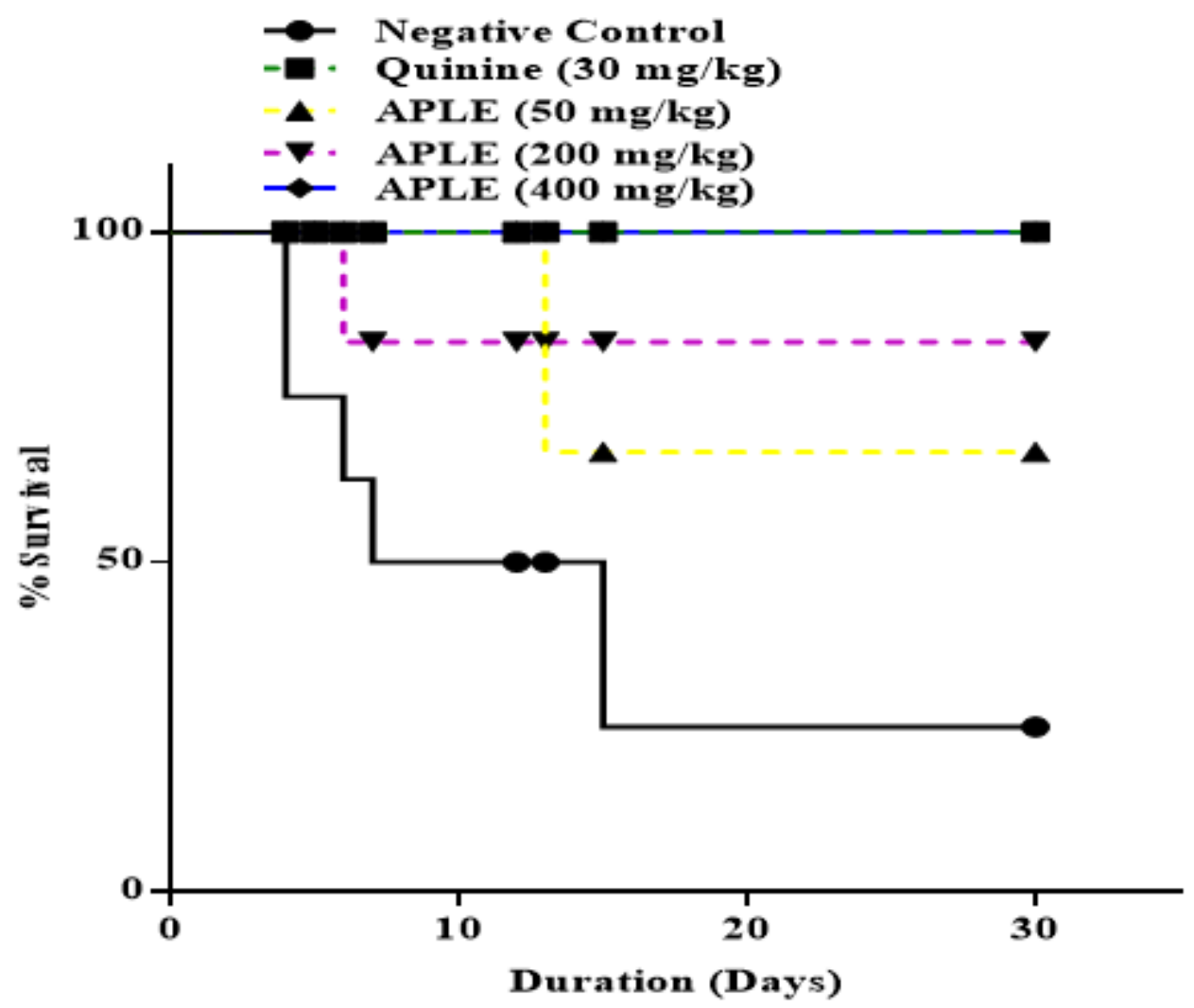

Figure 2 
Effect of APLE or Quinine on the survival rate of P. berghei-infected mice after 30 days of infection. Data was analyzed using the Kaplan-Meier method.

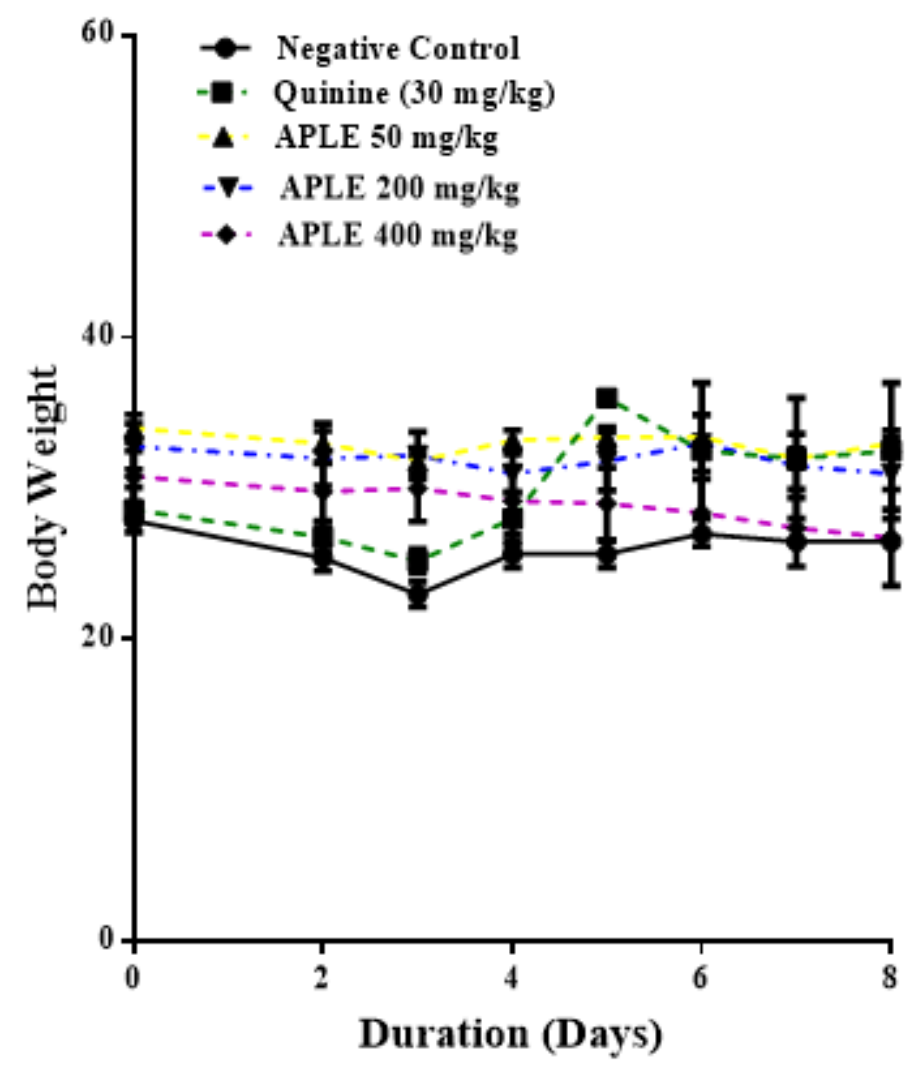

Figure 3

Effect of APLE or Quinine on body weight of P. berghei-infected mice on time course curve. Each point represents mean \pm S.E.M $(n=5)$. 

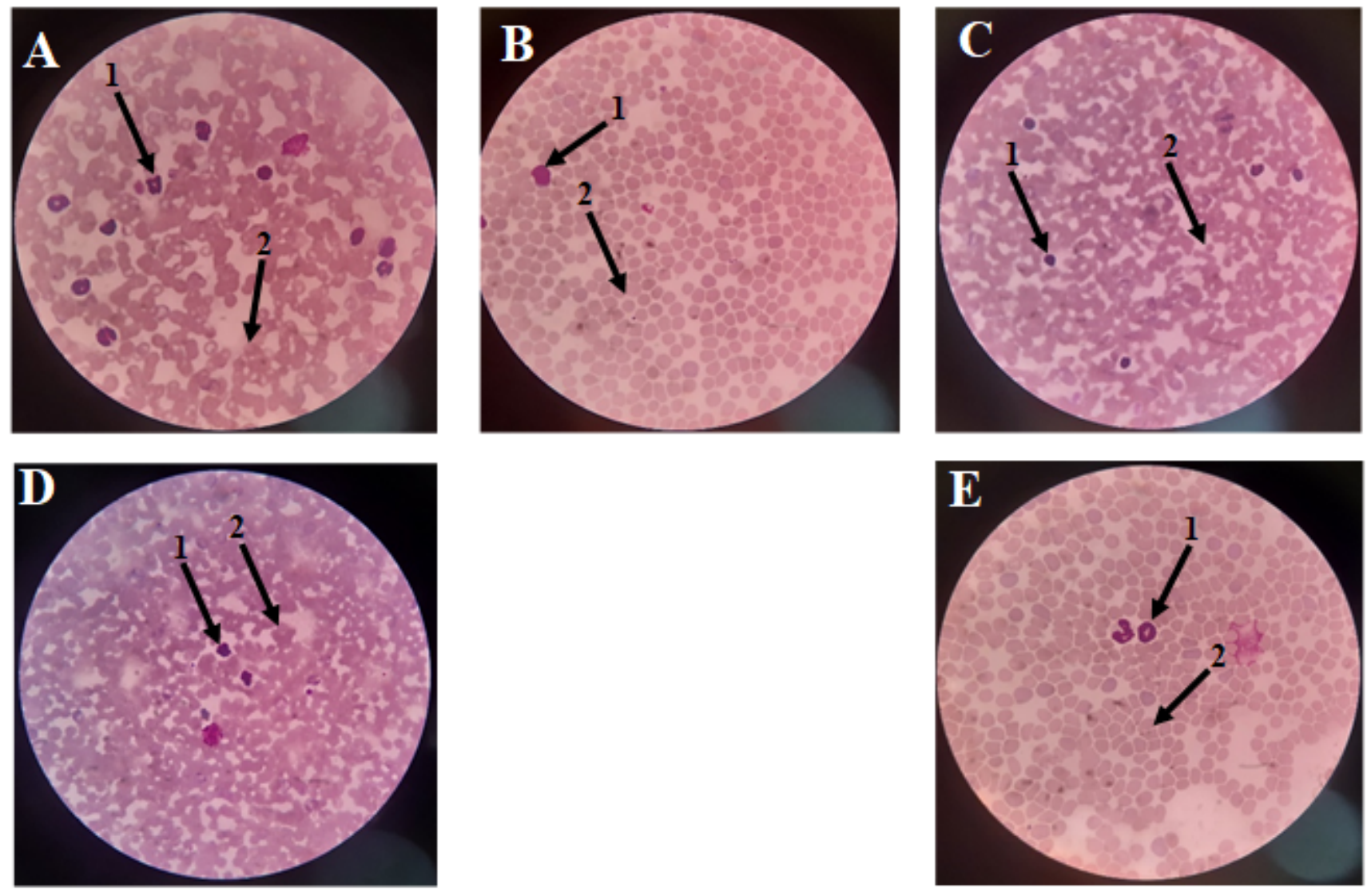

Figure 4

Micrographs showing selected fields of the levels of P. berghei infected and uninfected RBCs of both Negative control group (A) and the treatment groups (Quinine (B), APLE $50 \mathrm{mg} / \mathrm{kg}$ (C), $200 \mathrm{mg} / \mathrm{kg}$ (D) and $400 \mathrm{mg} / \mathrm{kg}(\mathrm{E})$ respectively on the 8th day. $1=$ infected $\mathrm{RBC}, 2=$ normal $\mathrm{RBC}$.

\section{Supplementary Files}

This is a list of supplementary files associated with this preprint. Click to download.

- Methodsformulas.docx 